\title{
The importance of information upon applying IFRS in financial entities that trade at the Colombian stock market ${ }^{*}$
}

\section{La importancia de la información en la \\ aplicación de las NIIF}

en las entidades financieras que cotizan en el mercado de valores colombiano

Miguel Angel Laverde Sarmiento** Jorge Fernando Garcia Carrillo*** Juan Carlos Lezama Palomino Alejandra Patiño Jacinto

Recibido: 30 de enero de 2019

Revisado: 20 de febrero de 2019

Aprobado: 6 de marzo de 2019

* Cómo citar: Laverde, M. A., García, J. F., Lezama, J. C. y Patiño, A. (2019). The importance of information upon applying IFRS in financial entities that trade at the Colombian stock market. Revista CIFE: Lecturas de Economía Social, 21(34), 137-152

DOI: https://doi.org/10.15331/22484914.5200

* Master of Economic Sciences from Santo Tomas University. Orcid: https:/ / orcid.org/0000-0002-6006-9195

*** Master of Economic Sciences from Santo Tomas University. Orcid: https://orcid.org/0000-0003-1248-1094

**** Master Degree in Economics from Nacional University. Orcid: https://orcid.org/0000-0003-1248-1094

***** Master of Economic Sciences from Santo Tomas University. Orcid: https://orcid.org/0000-0001-6017-7666 


\section{Abstract}

The aim of this research is to determine whether the implementation of the International Financial Reporting Standards (IFRS) in the companies of the financial sector listed on the Colombian Stock Exchange has greater relevance compared to the previous accounting regulatory framework known as Generally Accepted Accounting Principles (GAAP) in Colombia, for the years 2009 to 2016. Taking into account the concept of valorative relevance that indicates that the accounting information is relevant if it affects the stock price reflected in the capital market exchange.

To determine this relationship, an adaptation of the model proposed by Ohlson (1995) is used, because it is the most frequently used to measure relevance. The modifications made to the model were to include accounting variables of financial instruments of assets and liabilities to better measure the impact of the IFRS. On a general level, the conclusion is reached that the valorative relevance of financial companies listed on the stock exchange between 2009 and 2016, does not change due to the application of the IFRS. The results are because the regulation that financial companies that are listed on the stock exchange of Colombia are subject to has contributed to the relevance being maintained before and after the application of the new regulatory framework. However when carrying out the study of the information taking into account only the variables and taking into account the regulations under the IFRS, they present a greater degree of significance.

Keywords: Value relevance of information, Ohlson model, financial instruments, IFRS, generally accepted accounting principles.

Classification JEL: D53, G12, M41, C01.

\section{Resumen}

El propósito de esta investigación es determinar si la implementación de las normas internacionales de información financiera (NIIF) en las empresas del sector financiero que cotizan en la Bolsa de Valores de Colombia tiene mayor relevancia en comparación con el marco normativo contable anterior conocido como los Principios de Contabilidad Generalmente Aceptados (GAAP) en Colombia, para los años 2009 a 2016. Teniendo en cuenta el concepto de relevancia valorativa que indica que la información contable es relevante si afecta el precio de las acciones reflejado en el mercado de capitales.

Para determinar esta relación, se utiliza una adaptación del modelo propuesto por Ohlson (1995), ya que es el más utilizado para medir la relevancia. Las modificaciones hechas al modelo debían incluir variables contables de instrumentos financieros de activos y pasivos para medir mejor el impacto de las NIIF. A nivel general, se llega a la 
conclusión de que la relevancia valorativa de las compañías financieras que cotizaban en la bolsa de valores entre 2009 y 2016 no cambia debido a la aplicación de las NIIF. Los resultados se deben a que la regulación a la que están sujetas las compañías financieras que cotizan en la Bolsa de Valores de Colombia ha contribuido a que la relevancia se mantenga antes y después de la aplicación del nuevo marco regulatorio. Sin embargo, al realizar el estudio de la información teniendo en cuenta solo las variables y teniendo en cuenta las regulaciones bajo las NIIF, estos presentan un mayor grado de importancia.

Palabras clave: relevancia valorativa de la información, modelo de Ohlson, instrumentos financieros, NIIF, principios de contabilidad generalmente aceptados.

\section{Introduction}

Financial information is a fundamental element in business since it provides fundamental data for economic decision-making and for the control of resources. In this scenario, the needs and requirements for the multiple users are different and from there derive the rules, recognition structures, measurements and the different forms of presentation of financial information.

To meet these requirements there, exist several regulatory frameworks which are responsible for giving structure to this financial information, and one of the most widely used worldwide is the International Financial Reporting Standards (IFRS), which are being implemented in different countries, including Colombia, due to its recognition and reputation of quality. Additionally, Rodriguez, Cortez, Mendez, \& Garza (2013) state that the purpose of this information is for transparency and is an input for decision making in the securities markets. However, with the application of this normative framework, there is a need to evaluate whether the objectives set out there are being met, especially in the Latin American countries where this process is most recent (Patiño \& Vasquez, 2013).

Due to the great objective of the Colombian government when applying this framework in order to have a homogenous accounting system with international guidelines, the purpose of this article is to identify whether or not this implementation has any positive effect on companies, starting from the analysis of some of the characteristics of financial information. The first thing to keep in mind is that this normativity establishes qualitative characteristics, which are the basis for the measurement and presentation of information, within these, the pillars of the presentation are relevance and faithful representation. This relevance occurs when the information "is able to influence the decisions made by users and may be able to influence a decision even if some users choose not to take advantage of it or are already aware of it from other sources" (International Accounting Standards Board, 2016, p. 33). This is how relevance is focused on the perspective of useful information for decision-making. 
Additionally, several authors describe relevance, as is the case of Bogstrand \& Larsson (2012) who argue that information has this characteristic, when data is presented that serves to evaluate corporate growth, profitability and risk, all focused on the profit paradigm for decision making. Beisland (2009); Barth, Beaver \& Landsman (2001), Francis \& Schipper (1999) agree that this concept exists when the information is determined by the association or relationship between the book values and the equity market values. Holthanusen \& Watts (2001) state that this quality of information is evaluated based on equity and the fair value is not relevant.

Relevance has different perspectives and this depends on the events that are emerging in an economy and in a specific country, for example at the end of the sixties the informative perspective based on the prices of the shares. Later in the nineties, the analysis of the utility of the decision making where the relation of accounting with the stock market is analyzed by means of regressions taking data and broader periods, as evidenced in table 1 .

Table 1. Perspectives of the relevance of financial information

\begin{tabular}{lll} 
Perspective & \multicolumn{1}{c}{ Concept } & \multicolumn{1}{c}{ Measurement } \\
Informative & $\begin{array}{l}\text { The information is relevant when } \\
\text { it impacts the market prices of the } \\
\text { securities - predictive capacity-. }\end{array}$ & $\begin{array}{l}\text { Through indicators of profitability } \\
\text { and increase of profits. }\end{array}$ \\
$\begin{array}{l}\text { Profit for } \\
\text { decision making }\end{array}$ & $\begin{array}{l}\text { Information is relevant if it has } \\
\text { an impact on market values and } \\
\text { therefore is useful for making } \\
\text { decisions. }\end{array}$ & $\begin{array}{l}\text { Models of association between } \\
\text { accounting and market variables. } \\
\text { Models of association between } \\
\text { accounting and market variables } \\
\text { (based on changes). }\end{array}$
\end{tabular}

Source. Vasquez (2005)

Because the measurement of the quality of the information can become subjective and the characteristics of the information are diverse, in this work the relevance of the information is taken as a measurement variable and it is intended to put forth an opinion on whether the adoption of this new regulatory framework in Colombia has positive or negative effects for companies.

To demonstrate the relevance of financial information, the perspective of the utility for the decision-making presented in table 1 uses the Feltham-Ohlson model that determines the relevance of the value between the accounting variables and the market variables. Beisland (2009), this model uses the efficiency of the markets, which are in the accounting market research based accounting research (MBAR) (Ball \& Brown, 1968; Beaver, 1981).

To carry out the research initially a theoretical framework is made in which the main research similar to the work object is evidenced. Then the methodology is presented in which the econometric model to be used is detailed as well as the data that will be taken, 
then the results of the application of the model are explained and finally the conclusions of the work are set forth.

\section{Review of literature}

Current quantitative studies regarding the relevance of information focus on measuring the value relevance by means of the Ohlson model to determine how accounting data has affected the price of companies in various countries. Some of the results of implementing this model indicate that, when applying international standards, market liquidity increases, the cost of capital decreases and the valuation of shares increases when they meet the legal standards (Daske, Hail, Leuz \& Verdi, 2008), in this regard Sovbetov (2015) through his econometric estimation, indicates that the profitability and leverage indicators improve but not the efficiency and liquidity indicators. To analyze the main scopes of different authors, the main investigations related to the subject are mentioned:

Among the investigations that show the effect of financial information in the valuation of companies is the one developed by Alali \& Foote (2012), that by means of an estimate based on ordinary least squares, analyzed the liquid equity per share and the profits of 65 companies listed on the Dubai stock exchange between 2005 and 2006, determining that there is a positive association between the value of the shares and these accounting variables, and that over time the relevance of the information has improved. On the other hand, Gonçalves, Batista, Macedo \& Marques (2014) by means of the model of Collins, Edward, \& Weiss (1997) analyzed the relevance of the equity and earnings per share of the non-financial companies with the highest BM \& FBOVESPA share price between 2009 and 2010 and were able to identify that the information determined under local regulations was not statistically significant, contrary to the result obtained once the IFRSs were implemented, due to the fact that being oriented to the capital market better reflected the economic reality of the companies.

For these studies an important factor in order to measure the effect in the valuation of the companies, is the time of application of the standard, which can generate inconclusive results when the implementation time is recent; However, in early studies an improvement was observed in the relevance of the information and its comparability in the countries of Argentina, Chile, Brazil and Mexico when the basis of preparation is based on IFRS (Rodriguez et al., 2017). Similarly, it can be identified by using the Ohlson model or another econometric estimation, that the relevance of financial information improves in companies that implement international standards as happened in the Scandinavian countries (Bogstrand \& Larsson, 2012), companies in China (Rutledge, Karim y Gong, 2015), those emerging from Africa and some regions of Asia (Chebaane \& Othman, 2014); because there is a positive relationship between the profits and the assets of the companies analyzed, which allows us to conclude that 
the better your financial information, the greater the contribution in the investors' decision making, reflected through the price of the action.

In relation to the improvement of the quality of the financial information, Cardona (2016) by means of an estimate based on the adjusted Ohlson model, determines that applying the international standard in the listed companies of the main capital markets of South America does not present an improvement with respect to local regulations because the information provided to investors has a greater level of detail; however, there is evidence that there is a greater relevance in earnings per share when companies report losses and that the level of association between the book value (net equity) and the share price is statistically significant in normal situations.

On the other hand, Malaquias \& Lemes (2013) when analyzing the information of the financial information of 240 non-financial companies quoted in the Brazilian and US market, determine that the Brazilian market reports have a lower level of disclosure than those made in the United States of America and the companies of the Regulated sectors. This happens because the reports issued in the US market provide more detailed information on financial instruments.

Not only the relevance is given by the direct relationship between the accounting data and the stock price, but there are also other variables that improve this characteristic of the information such as the characteristics of several emerging countries, such as the high degree of economic openness, strong investor protection, full protection of minority shareholders and sophisticated capital markets (Chebaane \& Othman, 2014; Elbakry, Nwachukwu, Abdou \& Elshandidy, 2017; Garza, Martinez \& Palacio, 2013; Gonçalves, Lunga, da Silva \& da Costa, 2014; Rutledge et al., 2015). Another variable that can create an affect is the one mentioned by Rodriguez et al. (2013) who states that the relevance increases when the information is reviewed by a recognized auditing firm because it shows confidence in the financial statements.

\section{Methodology}

To measure whether or not the relevance had undergone any changes with the adoption of IFRS, the aforementioned model of Ohlson (1995) was used, since it allows for evaluating the company by means of accounting variables, modifying the model to include other accounting variables of financial instruments of assets and liabilities, and a dummy variable to measure the impact of the adoption of the IFRS.

For the development of the model, the accounting information from 2009 to 2016, reported in the Financial Superintendency of the published financial statements of 7 companies belonging to the financial sector, which are quoted on the Colombian Stock 
Exchange was used (BVC) During the period from 2009 to 2016, 224 observations were obtained. For the value of the share listed in the BVC following the methodology of Barth, Beaver \& Landsman (2001), the quoted price was used, six months after publication of the financial statements, thus ensuring that the information is available for analysis by the investors and the market can assess this information.

The variables of the study include the values of the financial instruments for liquidity management (Assets), investments (Assets) and financing (Liabilities) following IAS 39 and IFRS 9 since these are the main financial instruments that an Investor considers at the time of evaluating a company, also and included the liquid equity per share (PLPA), the profit per share (GPA) and the share price. Finally, two control variables are left to determine if the stock price is also explained by the accounting data of the non-financial assets on assets and the participation of non-financial liabilities. To guarantee the normal distribution of the data, all the accounting variables of the model are transformed natural logarithm, which reduces the asymmetry and the kurtosis of the data.

To calculate the PLPA, the company's equity was taken and divided by the number of shares, and for the GPA the profit for the year was taken and divided by the number of shares. The financial assets variables were taken as short-term investments and accounts receivable, for non-financial assets the total of the asset minus the financial assets was taken. For financial liabilities, accounts payable, financial obligations and bonds issued were taken. As for non-financial liabilities, the liability was taken minus the financial liability. The following table presents the statistical description of the variables:

Table 2. Statistical description of the variables

\begin{tabular}{|c|c|c|c|c|c|c|}
\hline Variable & Abbreviation & Observations & Media & $\begin{array}{l}\text { Standard } \\
\text { deviation }\end{array}$ & Min & $\operatorname{Max}$ \\
\hline Liquid equity per share & PLPA & 224 & $7,972,622$ & $2,048,788$ & 476,755 & $1,076,715$ \\
\hline Earnings per share & GPA & 224 & $5,237,613$ & $2,056,098$ & 177,905 & $8,705,053$ \\
\hline $\begin{array}{l}\text { Participation of } \\
\text { financial liquidity } \\
\text { instruments over assets }\end{array}$ & IFL & 224 & $2,61 \overline{0,798}$ & .5297481 & - 4,686,485 & $-1,745,032$ \\
\hline $\begin{array}{l}\text { Share of financial } \\
\text { investment instruments } \\
\text { on assets }\end{array}$ & IFI & 224 & $1,494,115$ & .5040739 & $-2,335,361$ & -.0668912 \\
\hline $\begin{array}{l}\text { The participation of } \\
\text { financial instruments } \\
\text { for financing liabilities }\end{array}$ & $\mathrm{IFF}$ & 224 & -.1023653 & .0811156 & -.5738028 & -.0010067 \\
\hline $\begin{array}{l}\text { Share of non-financial } \\
\text { assets over assets }\end{array}$ & ANF & 224 & -.5010072 & .5156871 & $-3,026,865$ & -.1959083 \\
\hline $\begin{array}{l}\text { Share of non-financial } \\
\text { liabilities over liabilities }\end{array}$ & PNF & 224 & $\begin{array}{c}- \\
2,784,297\end{array}$ & $1,118,913$ & $-6,901,568$ & -.8286897 \\
\hline Share Price & $\begin{array}{l}\text { VALUE } \\
\text { ACTION }\end{array}$ & 224 & 18133.08 & 20706.26 & 150 & 70,020 \\
\hline Colcap Index & COLCAP & 224 & $1,488,132$ & $2,516,263$ & 857,075 & $1,837,048$ \\
\hline
\end{tabular}

Source. From the authors 


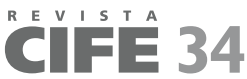

Revista CIFE / ISSN: 0124-3551 e-ISSN: 2248-4914 / Bogotá-Colombia / Vol. 21 N.o 34 / enero-junio 2019 / pp. $137-152$

To evaluate whether or not the adoption of IFRS affected the relevance for the quoting companies of the financial sector and if the financial instruments had any incidence on the relevance, four hypotheses were postulated.

$\mathrm{H1}$ : The accounting information with the adoption of IFRS improves the value relevance for the contributing companies of the financial sector.

$\mathrm{H} 2$ : The information of financial instruments valorizes the market in a different way depending on the accounting regulations under which it is prepared.

H3: The non-financial information valuates the market in a different way depending on the accounting regulations under which it is prepared.

$\mathrm{H} 4$ : The share value is explained by the accounting figures and by the valuation of the market as a whole.

In order to develop the first hypothesis $\mathrm{H} 1$ the Olson model was applied by adding a dummy variable using a data panel, which is used to determine if value relevance changes in a period. This is the proposed model:

$$
P_{i, t}=\theta_{0}+\theta_{1} P L P A_{i, t}+\theta_{2} G P A_{i, t}+D_{t}+\epsilon_{i}
$$

Where:

$P_{i, t}=$ Price of business $i$ in the $t$ quarter

$\theta_{0}=$ Intercept, $\theta_{1}=$ PLPA Estimator, $\theta_{2}=$ GPA Estimator,

$D_{t}=$ Dummy is 0 if the accounting data is prepared with COLGAAP and 1 it is with IFRS

$P L P A_{i, t}=$ Liquid Assets per share of business $i$ in the $t$ quarter

$G P A_{i, t}=$ Profit per share of company i quarter $t$

$\epsilon_{i}=$ The error could be decomposed randomly or fixed $v_{i}$ based on the model and partially randomly

In order to develop the second hypothesis $\mathrm{H} 2$ a model is applied based on the works by Gonçalves, Batista, da Silva Macedo, \& da Costa Marques (2014) and Huian (2015):

$$
P_{i, t}=\theta_{0}+\theta_{1} I F L_{i, t}+\theta_{2} I F I_{i, t}+\theta_{3} I F F_{i, t}+D_{t}+\epsilon_{i}
$$

Where:

$P_{i, t}=$ Business $i$ price at the $t$ quarter

$\theta_{0}=$ Intercept, $\theta_{1}=$ IFL Estimator , $\theta_{2}=$ IFI Estimator, $\theta_{3}=$ IFF Estimator 
$I F L_{i, t}=$ Financial liquidity instruments on the assets of the company $i$ in the quarter $t$

$I F L_{i, t}=$ Financial instruments of investments on the assets of the company $i$ in the quarter $t$

$I F L_{i, t}=$ Financial instruments financing company $i$ in the quarter $t$

$D_{t}=$ Dummy is 0 if the accounting information is prepared with COLGAAP and 1 if it is with IFRS

$\epsilon_{i}=$ The error can be broken down into a random or fixed part $v_{i}$ according to the model and a random part $u_{i}$

In order to develop the hypothesis $\mathrm{H} 3$ the non-financial variables of assets and liabilities were added to determine if the valuation is exclusive or not of the financial instruments, the following model was used:

$$
P_{i, t}=\theta_{0}+\theta_{1} I F L_{i, t}+\theta_{2} I F I_{i, t}+\theta_{3} I F F_{i, t}+\theta_{4} A N F_{i, t}+\theta_{4} P N F_{i, t}+D_{t}+\epsilon_{i}
$$

Where:

$P_{i, t}=$ Price of $i$ company in the $t$ quarter

$\theta_{0}=$ Intercept, $\theta_{1}=$ IFL Estimator, $\theta_{2}=$ IFI Estimator, $\theta_{3}=$ IFF Estimator, $\theta_{4}=$ IFL Estimator, $\theta_{5}=$ IFI Estimator

$I F L_{i, t}=$ Financial liquidity instruments on the assets of the company $i$ in the quarter $t$

$I F I_{i, t}=$ Financial instruments of investments on the assets of the company $i$ in the quarter $t$

$I F F_{i, t}=$ Financial instruments financing company $i$ in the quarter $t$

$A \mathcal{N F} F_{i, t}=\mathcal{N o n - f i n a n c i a l ~ a s s e t s ~ o f ~ t h e ~ c o m p a n y ~} i$ in the quarter $t$

$P \mathcal{N F} F_{i, t}=\mathcal{N o n - f i n a n c i a l ~ l i a b i l i t i e s ~ o f ~ t h e ~ c o m p a n y ~} i$ in the quarter $t$

$D_{t}=$ Dummy is 0 if the accounting information is prepared with COLGAAP and 1 if it is with IFRS

$\epsilon_{i}=$ The error can be broken down into a random or fixed part $v_{i}$ according to the model and a random part $u_{i}$

To answer the fourth hypothesis H4, the COLCAP index, which will be the proxy variable of the market, was included in the previous model, thus determining whether or not the valuation obeys exclusively to the behavior of the market or the accounting information.

$$
P_{i, t}=\theta_{0}+\theta_{1} I F L_{i, t}+\theta_{2} I F I_{i, t}+\theta_{3} I F F_{i, t}+\theta_{4} A N F_{i, t}+\theta_{4} P N F_{i, t}+\theta_{5} C O L C A P_{t}+D_{t}+\epsilon_{i}
$$

Where:

$P_{i, t}=$ Price of the company $i$ in the quarter $t$ 
Revista CIFE / ISSN: 0124-3551 e-ISSN: 2248-4914 / Bogotá-Colombia / Vol. 21 N.o 34 / enero-junio 2019 / pp. $137-152$

$\theta_{0}=$ Intercept, $\theta_{1}=$ IFL Estimator, $\theta_{2}=$ IFI Estimator, $\theta_{3}=$ IFF Estimator, $\theta_{4}=$ IFL Estimator, $\theta_{5}$ = IFI Estimator, $\theta_{3}=$ COLCAP Estimator

$I F L_{i, t}=$ Financial liquidity instruments on the assets of the company $i$ in the quarter $t$

$I F I_{i, t}=$ Financial instruments of investments on the assets of the company $i$ in the quarter $t$

$I F F i, t=$ Financial instruments financing company $i$ in the quarter $t$

$A \mathcal{N F} F_{i, t}=\mathcal{N o n}$-financial assets of the company $i$ in the quarter $t$

$P \mathcal{N} F_{i, t}=\mathcal{N}$ on-financial liabilities of the company $i$ in the quarter $t$

COLCAP $=$ COLCAP index in the quarter $t$

$D_{t}=$ Dummy is 0 if the accounting information is prepared with COLGAAP and 1 if it is with IFRS $\epsilon_{i}=$ The error can be broken down into a random or fixed part $v_{i}$ according to the model and a random part

\section{Results}

In this section, we analyze the results of the econometric estimations, which used to analyze the relevance of the financial information based on what proposed in each one of the hypotheses.

Initially the Hausman test (1978) is used to identify whether the estimation must be fixed or by random effects, where:

$$
H=\left(\beta_{c}-\beta_{e}\right)^{\prime}\left(V_{c}-V_{e}\right)^{-1}\left(\beta_{c}-\beta_{e}\right), H \sim X_{n}^{2}
$$

$\beta_{\mathrm{c}}=$ Belongs to the estimator vector of the consistent estimator (

$\beta_{\mathrm{e}}=$ Belongs to the estimator vector of the consistent estimator (

$V_{c}=\mathrm{It}$ is the matrix of the consistent estimator

$V_{c}=\mathrm{It}$ is the matrix of the efficient estimator

$n=$ The degrees of freedom in the number of variables squared included (

The findings of this test indicate that there are no systematic differences because the value of the test is low ( $\mathrm{p}$-valor $>0,05$ ), so the null hypothesis occurs and the random effects estimation is chosen because it is more efficient.

Initially the econometric model run to compare the accounting information with the IFRS and with COLGAP, for this, the first hypothesis that states that the accounting information with the adoption of the IFRS is relevant for the quoting companies of the financial sector. Table 3 took the variables PLPA, GPA and dummy as independent 
variables and the value of the company's action as a dependent variable, where can be identified that the only variable with significance is PLPA, this means that, as there is an increase in this variable, the share price of the entities that are being analyzed will increase. However, in this hypothesis understood that independent that the accounting information is relevant regardless of the regulatory framework that is used.

The second hypothesis, within the same analysis of the comparability between the IFRS and COLGAP, is that of valuing the market in a different way by means of the information of the financial instruments depending on the accounting rules for this, the variables PLPA, GPA, DUMMY, IFL, IFI and IFF as independent variables and the variable dependent on the value of the company's share. In this analysis, there are two significant variables, the first one is the PLPA and the other one is IFI, and that is to say, that expanding the analysis the Financial Instruments of Investment positively affects the value of the share. However, the Dummy variable remains insignificant.

Similarly, in the third hypothesis, the normativity is not relevant when analyzing relevance, the only variation in this analysis is that only the IFI variable is no longer significant, as in the hypothesis 4. An additional analysis of the accounting information is undertaken only with the data presented in COLCAP to later review the findings that the IFRS gives and thus make a contrast, in the analysis of the different hypotheses, in all, the liquid equity variable per share is highly significant and in hypothesis two so is the variable financial investment instruments. However, none of the other variables is representative, for the reason that can concluded that the information based on these normative models is not relevant as a whole.

Table 3. Analysis of the hypothesis of the general model

\begin{tabular}{lcccc} 
Variables & $\begin{array}{c}\text { Hypothesis 1 } \\
\text { Share price }\end{array}$ & $\begin{array}{c}\text { Hypothesis 2 } \\
\text { Share price }\end{array}$ & $\begin{array}{c}\text { Hypothesis 3 } \\
\text { Share price }\end{array}$ & $\begin{array}{c}\text { Hypothesis 4 } \\
\text { Share price }\end{array}$ \\
\hline PLPA & $3930.6^{* * * *}$ & $5609.0^{* * * * *}$ & $8304.6^{* * * *}$ & $8242.3^{* * * *}$ \\
\hline Z & $(4.45)$ & $(6.01)$ & $(5.12)$ & $(4.94)$ \\
\hline GPA & -351.0 & -651.3 & 110.5 & 165.9 \\
\hline Z & $(-0.49)$ & $(-0.93)$ & $(0.07)$ & $(0.10)$ \\
\hline DUMMY & -477.7 & -1.524 & 168.3 & 318.3 \\
\hline Z & $(-0.66)$ & $(-0.00)$ & $(0.09)$ & $(0.15)$ \\
\hline IFL & N/A & $1937.4^{*}$ & $7684.5^{* * * *}$ & $7740.8^{* * * *}$ \\
Z & - & $(2.39)$ & $(4.02)$ & $(3.98)$ \\
\hline IFI & N/A & $5445.9^{* * * *}$ & 5202.2 & 5341.5 \\
Z & - & $(3.77)$ & $(1.54)$ & $(1.54)$ \\
IFF & N/A & -6652.8 & 23099.1 & 22854.9 \\
$Z$ Z & - & $(-1.57)$ & $(1.15)$ & $(1.13)$ \\
\hline
\end{tabular}


Revista CIFE / ISSN: 0124-3551 e-ISSN: 2248-4914 / Bogotá-Colombia / Vol. 21 N.o 34 / enero-junio 2019 / pp. $137-152$

\begin{tabular}{lcccc} 
Variables & $\begin{array}{c}\text { Hypothesis 1 } \\
\text { Share price }\end{array}$ & $\begin{array}{c}\text { Hypothesis 2 } \\
\text { Share price }\end{array}$ & $\begin{array}{c}\text { Hypothesis 3 } \\
\text { Share price }\end{array}$ & $\begin{array}{c}\text { Hypothesis 4 } \\
\text { Share price }\end{array}$ \\
\hline ANF & N/A & N/A & -648.1 & -572.2 \\
\hline $\mathrm{Z}$ & - & - & $(-0.20)$ & $(-0.18)$ \\
\hline $\mathrm{PNF}$ & $\mathrm{N} / \mathrm{A}$ & $\mathrm{N} / \mathrm{A}$ & 2808.5 & 2785.5 \\
\hline $\mathrm{Z}$ & - & - & $(1.67)$ & $(1.65)$ \\
\hline $\mathrm{COLCAP}$ & $\mathrm{N} / \mathrm{A}$ & $\mathrm{N} / \mathrm{A}$ & $\mathrm{N} / \mathrm{A}$ & 0.548 \\
\hline $\mathrm{Z}$ & - & - & - & $(0.17)$ \\
\hline $\mathrm{N}^{\circ}$ of observations & 224 & 224 & 224 & 224 \\
\hline $\mathrm{t}$ figures in brackets & & & & \\
${ }^{*} \mathrm{p}<0.05(5 \%)$, & ${ }^{* *} \mathrm{p}<0.01(1 \%)$, & ${ }^{* * * *} \mathrm{p}<0.001(10 \%)$ & & \\
\hline
\end{tabular}

Source. From the authors

To carry out a broader analysis, is take the same hypotheses raised above but only taking the data with the IFRS (table 4) and COLCAP (table 5), that is to say that the Dummy variable is not taken because it is not intended to contrast one model of the other. Table 4 identifies that if there is relevance of the information where the main variable that gives significance in all the hypotheses is the PLPA.

Table 4. Analysis of hypothesis for COLGAAP

\begin{tabular}{lcccc} 
Variables & Hypothesis 1 & Hypothesis 2 & Hypothesis 3 & Hypothesis 4 \\
\hline PLPA & Share price & Share price & Share price & Share price \\
\hline Z & $4233.2^{* * * *}$ & $7432.7^{* * * *}$ & $6357.9^{* * * *}$ & $6349.8^{* * *}$ \\
\hline GPA & $(4.17)$ & $(7.08)$ & $(3.39)$ & $(3.27)$ \\
\hline$Z$ & -114.6 & -80.06 & 2158.2 & 2165.8 \\
\hline IFL & $(-0.13)$ & $(-0.09)$ & $(1.13)$ & $(1.10)$ \\
\hline$Z$ & N/A & 1872.9 & $6239.0^{*}$ & $6247.0^{*}$ \\
\hline IFI & - & $(1.80)$ & $(2.54)$ & $(2.49)$ \\
$Z Z$ & N/A & $9319.8^{* * * *}$ & 3952.7 & 3970.2 \\
\hline IFF & - & $(5.11)$ & $(1.02)$ & $(0.99)$ \\
\hline$Z$ & N/A & -10801.7 & 11618.8 & 11578.3 \\
ANF & - & $(-1.76)$ & $(0.49)$ & $(0.48)$ \\
$Z$ Z & N/A & N/A & 485.3 & 495.5 \\
PNF & - & - & $(0.14)$ & $(0.14)$ \\
$Z$ Z & N/A & N/A & 1088.6 & 1084.8 \\
\hline & - & - & $(0.47)$ & $(0.46)$ \\
\hline
\end{tabular}




\begin{tabular}{|c|c|c|c|c|}
\hline \multirow{2}{*}{ Variables } & Hypothesis 1 & Hypothesis 2 & Hypothesis 3 & Hypothesis 4 \\
\hline & Share price & Share price & Share price & Share price \\
\hline COLCAP & N/A & N/A & N/A & 0.0705 \\
\hline $\mathrm{Z}$ & - & - & - & $(0.02)$ \\
\hline $\mathrm{N}^{\circ}$ Observations & 168 & 168 & 168 & 168 \\
\hline \multicolumn{5}{|c|}{$\mathrm{t}$ figures in brackets } \\
\hline
\end{tabular}

Source. From the authors

Table 5 analyze, where identified that in the first two hypotheses the only variable with high significance is the liquid equity per share in the other two hypotheses. All the variables have a high level of significance except the financial investment instruments variable.

Table 5. Analysis of the hypothesis by IFRS

\begin{tabular}{|c|c|c|c|c|}
\hline \multirow{2}{*}{ Variables } & Hypothesis 1 & Hypothesis 2 & Hypothesis 3 & Hypothesis 4 \\
\hline & Share price & Share price & Share price & Share price \\
\hline PLPA & $10989.7^{* * * *}$ & $9117.1^{* * * *}$ & $20905.9^{* * * *}$ & $20902.9^{* * * *}$ \\
\hline $\mathrm{Z}$ & $(3.90)$ & $(5.36)$ & (6.34) & $(6.27)$ \\
\hline GPA & -784.1 & -352.9 & $-11483.7^{* * *}$ & $-11476.0^{* * * *}$ \\
\hline $\mathrm{Z}$ & $(-1.13)$ & $(-0.29)$ & $(-4.17)$ & $(-4.12)$ \\
\hline IFL & $\mathrm{N} / \mathrm{A}$ & 3115.1 & $28135.5^{* * *}$ & $28119.3^{* * * *}$ \\
\hline $\mathrm{Z}$ & - & $(1.40)$ & $(6.40)$ & $(6.30)$ \\
\hline IFI & N/A & 1983.4 & -4848.8 & -4908.5 \\
\hline $\mathrm{Z}$ & - & $(0.44)$ & $(-0.33)$ & $(-0.33)$ \\
\hline IFF & $\mathrm{N} / \mathrm{A}$ & 2516.5 & $191434.9^{* * * *}$ & $191608.7^{* * * *}$ \\
\hline $\mathrm{Z}$ & - & $(0.37)$ & $(4.46)$ & $(4.40)$ \\
\hline $\mathrm{ANF}$ & $\mathrm{N} / \mathrm{A}$ & $\mathrm{N} / \mathrm{A}$ & $-59520.4^{*}$ & $-59597.2^{*}$ \\
\hline $\mathrm{Z}$ & - & - & $(-2.49)$ & $(-2.46)$ \\
\hline PNF & $\mathrm{N} / \mathrm{A}$ & $\mathrm{N} / \mathrm{A}$ & $16971.2^{* * *}$ & $16983.7^{* * * *}$ \\
\hline $\mathrm{Z}$ & - & - & (5.19) & (5.12) \\
\hline COLCAP & $\mathrm{N} / \mathrm{A}$ & $\mathrm{N} / \mathrm{A}$ & $\mathrm{N} / \mathrm{A}$ & 0.681 \\
\hline $\mathrm{Z}$ & - & - & - & $(0.04)$ \\
\hline $\mathrm{N}^{\circ}$ of Observations & 56 & 56 & 56 & 56 \\
\hline $\mathrm{t}$ figures in brackets & & & & \\
\hline$* \mathrm{p}<0.05$ & $* * \mathrm{p}<0.01$ & $* * * \mathrm{p}<0.001$ & & \\
\hline
\end{tabular}

Source. From the authors 


\section{Conclusions}

This research project intends to analyze whether the accounting information following the implementation of the International Financial Reporting Standards (IFRS) is relevant or not, based on the relevance of the information when the accounting data influences the prices of the shares of the companies. In order to achieve this objective, previous research studies analyzed and it concluded that the Ohlson model is the most suitable. Similarly, it evidenced that in most countries, the implementation had been positive to increase the degree of the information characteristic of the study; however, in some studies it is negative.

After organizing the information and applying the econometric model, in the first analysis it intended to evaluate if the implementation of the IFRS are more relevant than COLGAPS. When the different econometric studies were conducted taking into account the hypothesis, it is concluded that none of the dummy variables give significance, for this reason, the regulation is indifferent when it comes to measuring the relevance of the information. Additionally, the significance of the liquid equity variable per share (PLPA) and the investment financial instruments observed, because if this variable increases, the share price of the study companies' increases. This result is attributed to the fact that financial institutions, due to their national and international regulation, are subject to having high standards in the management and determination of accounting information and therefore this change does not generate an impact as in other economic sectors as has occurred in the different studies previously identified.

To analyze the accounting regulations separately, the same analysis of the hypotheses conducted, but initially only with data based on the IFRS, that is, the Dummy variable not taken into account because the contrast of one model omitted with the other. For this, Table N 5 analyzed in which it identified that the accounting information based on the IFRS is relevant because when considering all the study variables the only one that has a low level of significance is that of financial investment instruments.

On the other hand, the variables analyzed by only considering the regulations in COLGAP. As shown in Table N 4, the significant variable is the net equity per share and additionally in hypothesis two the variable financial investment instruments. Contrasting this analysis with that of the IFRS, it observed that these variables based on COLGAP present a lesser degree of relevance than IFRS.

The market values liquidity instruments better than non-financial assets because the degree of significance of the former is $99.9 \%$ while the latter is $95 \%$, in addition, financial investment instruments do not generate an impact in the share price according to this econometric estimation. Although the time of application of the IFRS is still too short to determine in a more concrete way its relevance; at a general level, it can be shown that there is a change in the valuation of the market in certain accounting items. 


\section{References}

Alali, F. \& Foote, P. S. (2012). The Value Relevance of International Financial Reporting Standards: Empirical Evidence in an Emerging Market. The International fournal of Accounting, 47(1), 85-108.

Ball, R. \& Brown, P. (1968). An empirical evaluation of accounting income numbers. Journal of Accounting Research, 159-178.

Barth, M., Beaver, W. \& Landsman, W. (2001). The relevance of the value-relevance literature for financial accounting standard setting: another view. Fournal of Accounting E Economics, 31, 77-104.

Beisland, L. (2009). A Review of the Value Relevance Literature. The Open Business fournal, 2, 7-27.

Bogstrand, O. \& Larsson, E. (2012). Have IFRS Contributed to an increased value-relevance. Retrieved from http://www.diva-portal.org/smash/get/diva2:546324/ FULLTEXT01

Callao, S., Jarne, J. \& Lainez, J. (2007). Adoption of IFRS in Spain: Effect on the comparability and relevance of financial reporting. Fournal of International Accounting, Auditing and Taxation, (16), 148-178.

Cardona, J. (2016). Efectos de las IFRS en la relevancia valorativa de las magnitudes contables en los principales mercados suramericanos. (Ponencia). Bogotá: Universidad Libre de Colombia.

Chebaane, S. \& Othman, H. (2014). The Impact of IFRS Adoption on Value Relevance of Earnings and Book Value of Equity: The Case of Emerging Markets in African and Asian Regions. Procedia - Social and Behavioral Sciences, 145, 70-80.

Collins, D., Edward, M. \& Weiss, I. (1997). Changes in the value-relevance of earnings and book values over the past forty years. Journal of Accounting and Economics, 39-67.

Daske, H., Hail, L., Leuz, C. \& Verdi, R. (2008). Mandatory IFRS Reporting around the world: Early evidence on the economic consequences. Fournal of Accounting Research, 46(5), 1085-1142.

Elbakry, A., Nwachkwu, J., Abdou, H. \& Elshandidy, T. (2017). Comparative evidence on the value relevance of IFRS-based accounting information in Germany and the UK. Fournal of International Accounting, Auditing and Taxation, (28), 10-30.

Francis, J. \& Schipper, K. (1999). Have financial statements lost their relevance? Fournal of Accounting Research, 37(2), 319-352. 
Revista CIFE / ISSN: 0124-3551 e-ISSN: 2248-4914 / Bogotá-Colombia / Vol. 21 N.o 34 / enero-junio 2019 / pp. $137-152$

Garza, H. Martinez, I. \& Palacio, M. (2013). Relevancia valorativa de la información financiera en América Latina: el caso de Argentina, Brasil, Chile y México. Retrieved from http://www. aecal.org/pub/on_line/comunicaciones_xviicongresoaeca/cd/118a.pdf

Gonçalves, J. C., Batista, B. L. L., da Silva Macedo, M. A. \& da Costa Marques, J. A. V. (2014). Análise do impacto do processo de convergência às normas internacionais de contabilidade no Brasil: um estudo com base na relevância da informação contábil. Revista Universo Contábil, 10(3), 25-43.

Hausman, J. (November, 1978). Specification Tests in Econometrics. Econometrica, 46(6), 1251-1271.

Holthanusen, R. \& Watts, R. (2001). The relevance literature of the value relevance for financial accounting standard setting. Journal of Accounting E्E Economics, (31), 3-75.

Huian, M. C. (2015). The usefulness of accounting information on financial instruments to investors assessing non-financial companies. An empirical analysis on the Bucharest Stock Exchange. Accounting and Management Information Systems, 748-769.

International Accounting Standards Board (2016). The conceptual framework for financial information.

Malaquias, R. \& Sirlei, L. (2013). Disclosure of financial instruments according to International Accounting Standards: empirical evidence from Brazilian companies. Brazilian Businees Review, 10(3), 82-107.

Patiño, R. \& Vasquez, N. (2013). Las características de los subsistemas contables de Colombia y México ante la convergencia a Normas Internacionales de Información Financiera. Cuadernos de Contabilidad, 14(36), 1009-1043.

Rodriguez, M., Cortez, K., Mendez, A. \& Garza, H. (2017). Does an IFRS adoption increase value relevance and earningstimeliness in Latin America? Emerging Markets Review (30), 155-168.

Rutledge, R., Karim, K. \& Gong, J. (2015). Convergence of PRG GAAP with IFRS, and the Comparative Value Relevance between the Two Sets of Reporting Standards: The Case of Dual-Listed Chinese Companies. Journal of Accounting and Finance, 15(4), 165-183.

Sovbetov, Y. (2015). How IFRS affects value relevance and key financial indicators. International Review of Accounting, Banking and Finance, 7(1), 73-96. 